\title{
Nowoczesne usługi a czynniki rozwoju społeczno-gospodarczego - analiza relacii w układzie państw Unii Europejskiej
}

\author{
Modern Services and Socio-Economic Development Factors - \\ Analysis of Relations in the System of European Union Countries
}

\begin{abstract}
Streszczenie: Celem artykułu jest analiza zmian relacji w zakresie rozwoju nowoczesnych usług, czynników rozwoju oraz poziomu rozwoju społeczno-gospodarczego w układzie państw Unii Europejskiej. W pracy podejmuje się próbę odpowiedzi na następujące pytania badawcze: (1) jak kształtują się zmiany poziomu rozwoju nowoczesnych usług w państwach UE w relacji do zmian rozwoju społeczno-gospodarczego; (2) jak w odniesieniu do tych relacji przedstawia się klasyfikacja państw UE i jakie zaszły w niej zmiany. Badania przeprowadzono dla dwóch momentów czasowych - 2008 i 2017 roku. W analizie wykorzystano wartości wskaźnika syntetycznego Perkala obliczonego dla nowoczesnych usług oraz czynników rozwoju oraz wartość wskaźnika PKB na jednego mieszkańca jako miernika poziomu rozwoju społeczno-gospodarczego W pierwszym kroku dokonano analizy zmian dotyczących poziomu rozwoju nowoczesnych usług oraz czynników rozwoju. W kolejnym etapie do analizy zależności włączono również poziom rozwoju społeczno-gospodarczego mierzony wartością PKB na jednego mieszkańca i na tej podstawie dokonano klasyfikacji państw UE. Grupowanie przeprowadzono z wykorzystaniem analizy skupień w oparciu o dane statystyczne zaczerpnięte z bazy Eurostat. Analiza prowadzi do wniosku, że większość państw w procesie rozwoju społeczno-gospodarczego podąża ścieżką prowadzącą od wzrostu nowoczesnych usług, przez wzmacnianie czynników rozwoju społeczno-gospodarczego i w konsekwencji do wyższego poziomu rozwoju nowoczesnej gospodarki.
\end{abstract}

\footnotetext{
Abstract: The purpose of the paper is to analyse relations changes in the development of modern services, factors and the level of socio-economic development in the system of the European Union countries. The paper attempts to answer the following research questions: (1) how the changes in the level of development of modern services in EU countries are in relation to changes in socio-economic development; (2) what is the classification of EU countries in reference to these relations. The research was carried out for two moments in time - 2008 and 20017. In the analysis, the values of the synthetic index calculated for modern services and development factors and the value of the GDP per capita indicator were used as a measure of the level of socio-economic development. In the first step, changes in the level of development of modern services and development factors were analysed. In the next stage, the analysis of dependence also included the level of socio-economic development measured by the value of GDP per capita and on this basis the classification of EU countries was made. Grouping was carried out using cluster analysis based on statistical data taken from the Eurostat database. The analysis leads to the conclusion that in the process of socio-economic de-
} 
velopment most countries follow the path leading from the growth of modern services, by strengthening the factors of socio-economic development and, as a consequence, to a higher level of development of the modern economy.

Słowa kluczowe: czynniki rozwoju; kraje UE; rozwój społeczno-gospodarczy; usługi nowoczesne Keywords: development factors; EU countries; modern services; socio-economic development

Otrzymano: 10 grudnia 2019

Received: 10 December 2019

Zaakceptowano: 10 lutego 2020

Accepted: 10 February 2020

Sugerowana cytacja / Suggested citation:

Dominiak, J. (2020). Nowoczesne usługi a czynniki rozwoju społeczno-gospodarczego - analiza relacji w układzie państw UE. Prace Komisji Geografii Przemysłu Polskiego Towarzystwa Geograficznego, 34(1), 20-31. doi: $10.24917 / 20801653.341 .2$

\section{WSTĘP}

Nowoczesne usługi, zwłaszcza te oparte na wiedzy, stanowią ważne ogniwo w procesie rozwoju społeczno-gospodarczego. Odgrywają one niezwykle istotną rolę m.in. w procesie kształtowania kapitału ludzkiego (usługi edukacyjne), w procesie generowania innowacji (sfera badawczo-rozwojowa) i ich dyfuzji (centra wspierania i transferu innowacji), dostępności kapitału finansowego (instytucje finansowe) czy wsparcia działalności firm (usługi profesjonalne) (Dominiak, 2019). Poprzez oddziaływanie na główne czynniki rozwoju nowoczesne usługi stają się filarem współczesnej gospodarki. Ich znaczenie wzrasta szczególnie w dobie nowoczesnej gospodarki opartej na wiedzy, w której głównymi czynnikami rozwoju stały się kapitał ludzki, społeczny i innowacyjność (Chojnicki, Czyż, 2006).

Innowacje stały się elementem, który odgrywa kluczową rolę w krystalizacji nowego modelu gospodarczego, szczególnie w państwach rozwiniętych (gdzie wzrost liczby ludności i konsumpcji jest trudny do osiągnięcia) (Kowalski, 2011; Churski i in., 2018). Powrót na ścieżkę dalszego rozwoju w tym modelu wymaga przemian strukturalnych ukierunkowanych na nowoczesne działalności o wysokiej produktywności, zarówno w przemyśle, jak i usługach (Rodrik, 2009). Wyniki prowadzonych badań wskazują, że funkcję takich kół napędowych gospodarki mogą pełnić usługi, szczególnie te nowoczesne, oparte na wiedzy (Felipe, Leon-Ledesma, Lanzafame, Estrada, 2007).

Celem artykułu jest analiza zmian relacji w zakresie rozwoju nowoczesnych usług, czynników rozwoju oraz poziomu rozwoju społeczno-gospodarczego w układzie państw Unii Europejskiej. W pracy podejmuje się próbę odpowiedzi na następujące pytania badawcze: (1) jak kształtują się zmiany poziomu rozwoju nowoczesnych usług w państwach UE w relacji do zmian rozwoju społeczno-gospodarczego; (2) jak w odniesieniu do tych relacji przedstawia się klasyfikacja państw UE i jakie zaszły w niej zmiany. W celu uchwycenia zachodzących zmian badania przeprowadzono dla dwóch momentów czasowych - lat 2008 i 2017.

Postępowanie badawcze składało się z dwóch etapów. W pierwszym dokonano analizy poziomu rozwoju nowoczesnych usług oraz operacjonalizacji czynników rozwoju społeczno-gospodarczego. W analizie wykorzystano wartości wskaźnika syntetycznego Perkala, obliczonego dla nowoczesnych usług oraz czynników rozwoju. W kolejnym etapie do analizy zależności włączono również poziom rozwoju społeczno-gospodarczego. 
W tym celu wykorzystano najpowszechniej stosowany wskaźnik poziomu rozwoju społeczno-gospodarczego, jakim jest produkt krajowy brutto (PKB) w przeliczeniu na jednego mieszkańca. Jest to zgodne z podejściem tradycyjnej ekonomii, gdzie rozwój społeczno-gospodarczy postrzega się jako wzrost produktu krajowego brutto, którego pomiar odbywa się z zastosowaniem wskaźnika odnoszącego jego wielkość do liczby mieszkańców (PKB na jednego mieszkańca). Grupowanie przeprowadzono z wykorzystaniem analizy skupień w oparciu o dane statystyczne zaczerpnięte z bazy Eurostat.

\section{ROLA NOWOCZESNYCH USŁUG W ROZWOJU SPOŁECZNO-GOSPODARCZYM}

Pojęcie nowoczesnych usług nie jest określeniem jednoznacznym. Zwykle w literaturze przedmiotu utożsamia się je z usługami opartymi na wiedzy, które dynamicznie rozwijają się w dobie gospodarki opartej na wiedzy. W niniejszej pracy za usługi nowoczesne przyjmuje się takie usługi, które spełniają dwa kryteria. Po pierwsze, założono, że są to usługi należące do grupy tzw. usług opartych na wiedzy lub usług o wysokim nasyceniu wiedzą (knowledge intensive services - KIS). Przyjęcie tego założenia ma tę zaletę, iż usługi te występują w oficjalnych klasyfikacjach działalności: NACE (fr. Nomenclature statistique des activités économiques dans la Communauté européenne), Polskiej Klasyfikacji Działalności (PKD), dzięki czemu możliwe jest pozyskanie danych statystycznych niezbędnych do analizy. Drugim kryterium wyróżniającym usługi nowoczesne jest ich dynamiczny rozwój, wyrażający się ponadprzeciętnymi wartościami wskaźników dynamiki oraz wzrostem ich udziału w strukturze usług według miernika zatrudnienia. Nałożenie na siebie tych dwóch kryteriów pozwoliło na wyróżnienie rodzajów działalności usługowych, które zostaną poddane szczegółowej analizie w dalszej części opracowania ${ }^{1}$. Należą do nich: usługi informatyczne, badawczo-rozwojowe, obsługa nieruchomości, usługi profesjonalne ${ }^{2}$, finansowo-ubezpieczeniowe oraz edukacyjne i medyczne. Na kolejnych etapach postępowania badawczego usługi związane z obsługą nieruchomości włączono do usług profesjonalnych i analizuje się je łącznie z usługi informatycznymi (ICT), traktując jako tzw. usługi dla biznesu (Dominiak, 2019).

Nowoczesne usługi stanowią ważne ogniwo w procesie rozwoju społeczno-gospodarczego. Przez oddziaływanie na podstawowe czynniki rozwoju społeczno-gospodarczego, takie jak kapitał ludzki, społeczny, finansowy, innowacyjność, warunkują i pobudzają rozwój gospodarki. W takich gospodarkach, których rozwój opiera się na wiedzy, innowacjach, procesie wspólnego uczenia się, znaczenie usług nowoczesnych rośnie jeszcze bardziej. Odgrywają one zasadniczą rolę w procesie tworzenia wiedzy (usługi edukacyjne), generowania i transferu innowacji (sfera badawczo-rozwojowa i środowisko innowacyjne) i przez to kształtowania innowacyjności i przewagi konkurencyjnej współczesnych gospodarek. Oczywiście, proces rozwoju innowacyjności jest bardziej złożony i do jego uruchomienia niezbędne są także inne zasoby, niemniej nie ulega wątpliwości, że wspomniane nowoczesne usługi stanowią jego niezbędny element.

Rozwój innowacyjności gospodarki w dużej mierze warunkowany jest także dostępnością kapitału finansowego. Tutaj ważną funkcję pełnią instytucje finansowe (w tym sektor bankowy, fundusze pożyczkowe, poręczeniowe, venture capital itp.) i ubezpieczeniowe. Sektor nowoczesnych usług wspomaga także przedsiębiorstwa na

${ }^{1}$ Analizę dynamiki poszczególnych rodzajów usług przeprowadzono w odniesieniu do państw UE w okresie 2002-2016 przy uwzględnieniu obu wersji klasyfikacji - NACE Rev. 1.1 oraz Nace rev. 2.

${ }^{2}$ Do usług profesjonalnych zaliczono sekcję M PKD 2007. 
etapie komercjalizacji nowych produktów czy technologii, oraz rozwoju działalności gospodarczej (przez usługi informacyjne, szkoleniowe, doradcze, marketingowe itp.). Ważnym elementem nowoczesnej gospodarki jest także proces wspólnego uczenia się (collective learning), który jest ściśle związany z rozwojem wiedzy i poziomu innowacyjności.

W nowoczesnej gospodarce główną siłą napędową rozwoju jest tworzenie i umiejętne wykorzystanie wiedzy. Stąd kluczowymi czynnikami rozwoju społeczno-gospodarczego stają się kapitał ludzki - ze względu na fakt, że wiedza ucieleśniona jest w człowieku, a także kapitał społeczny, który odgrywa istotną rolę w procesie przepływu oraz dyfuzji wiedzy i innowacji. Wiedza zawsze miała ważne znaczenie dla rozwoju, ale współcześnie stanowi podstawowe narzędzie zwiększania poziomu innowacyjności oraz najważniejsze źródło przewagi konkurencyjnej.

W oparciu o przegląd literatury przedmiotu znaczenie nowoczesnych usług w rozwoju społeczno-gospodarczym można sprowadzić do następujących relacji:

- usługi edukacyjne a kształtowanie kapitału ludzkiego, przede wszystkim w zakresie kwalifikacji i umiejętności (Camagni, 1991; Becker, 1993; Lundvall, 2000; Pakulska, 2005; Chojnicki, Czyż, 2006; Markowski, Drzazga, 2008),

- usługi badawczo-rozwojowe a innowacyjność (Aydalot, Keeble, 1988; Capello, Nijkamp, 2009; Uppenberg, 2009),

- usługi profesjonalne i ICT (usługi dla biznesu) i ich rola w obsłudze biznesu (patrz np. Werwicki, 1998; Keeble, Wilkinson, 1999; Longhi, 1999; Kłosiński, 2000),

- usługi finansowe a kapitał finansowy (Churski, Dominiak, 2014; Churski i in., 2018).

Rycina 1. Schemat analizy wpływu nowoczesnych usług na rozwój społeczno-gospodarczy

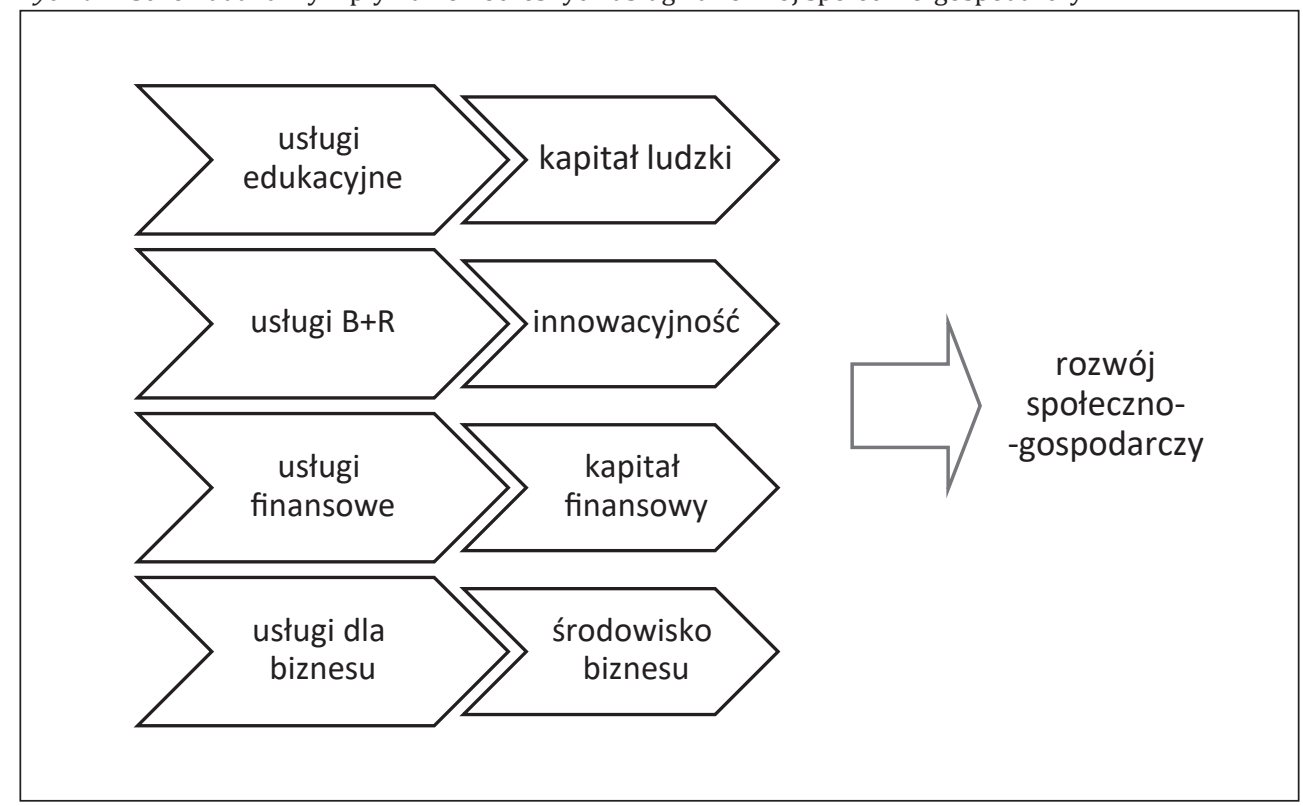

Źródło: opracowanie własne

${ }^{3}$ Patrz: Dominiak $(2017,2018)$, Dominiak, Hauke (2018). 


\section{ANALIZA ZALEŻNOŚCI: NOWOCZESNE USŁUGI - CZYNNIKI ROZWOJU - POZIOM ROZWOJU SPOŁECZNO-GOSPODARCZEGO W KRAJACH UE}

W analizie zależności: nowoczesne usługi - czynniki rozwoju - poziom rozwoju społeczno-gospodarczego w krajach UE wykorzystano wartości wskaźnika syntetycznego, obliczonego dla nowoczesnych usług, czynników rozwoju oraz wartość wskaźnika PKB na jednego mieszkańca jako miernik poziomu rozwoju społeczno-gospodarczego. Zastosowano wskaźnik syntetyczny Perkala ${ }^{4}$ w następującej postaci (Kostrubiec, 1965: 214):

gdzie:

$$
W_{s}=\frac{\sum_{j=1}^{p} y_{1}}{p}
$$

$W_{s}$ - wskaźnik syntetyczny,

$j-1,2, \ldots, \mathrm{p}$,

$p$ - liczba uwzględnionych cech,

$y_{i j}$ - standaryzowana wartość $j$-tej cechy dla $i$-tego obiektu

Do konstrukcji syntetycznego wskaźnika Perkala wykorzystano wskaźniki cząstkowe zamieszczone w tabeli 1.

Tabela 1. Wykaz cech wykorzystanych w analizie poziomu rozwoju nowoczesnych usług

\begin{tabular}{|c|c|}
\hline Nowoczesne usługi & Czynniki rozwoju \\
\hline $\begin{array}{l}\text { Usługi edukacyjne } \\
\text { E1 - odsetek pracujących w sekcji edukacja } \\
\text { E2 - odsetek dorosłych (powyżej } 25 \text { roku życia) } \\
\text { biorących udział w kształceniu }\end{array}$ & $\begin{array}{l}\text { Kapitał ludzki } \\
\text { K1 - wskaźnik aktywności ekonomicznej } \\
\text { K2 - odsetek osób z wykształceniem wyższym }\end{array}$ \\
\hline $\begin{array}{l}\text { Usługi badawczo-rozwojowe } \\
\text { B1 - GERD (euro na } 1 \text { mieszkańca) } \\
\text { B2 - GERD (\% PKB) } \\
\text { B3 - BERD } \\
\text { B4 - \% personelu B + R w ogóle aktywnych } \\
\text { zawodowo } \\
\text { B5 - \% personelu B +R w ogólnym zatrudnieniu }\end{array}$ & $\begin{array}{l}\text { Innowacyjność } \\
\text { I1 - \% pracujących w HTS } \\
\text { I2 - patenty na } 1 \text { mln mieszkańców }\end{array}$ \\
\hline $\begin{array}{l}\text { Usługi dla biznesu (w tym finansowe) } \\
\text { U1 - \% pracujących w usługach profesjonalnych } \\
\text { U2 - \% pracujących w usługach finansowych } \\
\text { i ubezpieczeniowych } \\
\text { U3 - \% pracujących w ICT }\end{array}$ & $\begin{array}{l}\text { Środowisko biznesu (kapitał finansowy) } \\
\text { P1 - wskaźnik zatrudnienia } \\
\text { P2 - odsetek długotrwale bezrobotnych } \\
\text { P3 - udział nowo zatrudnionych w ogólnym } \\
\text { zatrudnieniu } \\
\text { P4 - liczba podmiotów gospodarczych na } 1 \text { tys. } \\
\text { mieszkańców } \\
\text { P5 - inwestycje na } 1 \text { zatrudnionego w tys. euro }\end{array}$ \\
\hline
\end{tabular}

Źródło: opracowanie własne

Pierwszy etap postępowania badawczego polegał na analizie zmian dotyczących poziomu rozwoju nowoczesnych usług oraz czynników rozwoju. Do nowoczesnych usług, zgodnie z ustaleniami teoretycznymi, zaliczono: usługi edukacyjne, badawczo-rozwojowe oraz usługi dla biznesu i finansowe ${ }^{5}$, natomiast analizowanymi czynnikami rozwoju były: kapitał ludzki, innowacyjność i środowisko biznesu. Relacje między tymi

\footnotetext{
${ }^{4}$ Wskaźnik Perkala do oceny potencjału innowacyjnego województw wykorzystali m.in. Nowakowska, Feltynowski (2009: 11-24).

${ }^{5}$ Usługi finansowe i dla biznesu ze względu na podobieństwa w niniejszej analizie ujęto łącznie.
} 
dwoma elementami oraz ich zmiany w czasie w układzie państw UE przedstawia rycina 2. Analiza ta prowadzi do następujących wniosków:

- Skupienie państw o wysokim poziomie rozwoju nowoczesnych usług, wysokich wartościach wskaźników opisujących czynniki obejmuje państwa Europy Zachodniej i Północnej: Niemcy, Szwecję, Finlandię, Danię, Wielką Brytanię, Holandię, Irlandię. Wśród tych państw odnotowujemy nieznaczne spadki wartości wskaźników syntetycznych wynikających z dynamicznego rozwoju nowoczesnych usług w pozostałych krajach, a co za tym idzie, zmniejszanie się różnic w wartościach wskaźnika Perkala między krajami UE.

- Można także wyróżnić grupę państw o stosunkowo wysokim poziomie rozwoju nowoczesnych usług, którym towarzyszą relatywnie niższe wartości wskaźników opisujących czynniki rozwoju społeczno-gospodarczego. To Austria, Belgia i Francja.

- Kolejne skupienie obejmuje państwa cechujące się spadkiem swojej pozycji zarówno w odniesieniu do nowoczesnych usług, jak i do czynników rozwoju. To państwa Europy Południowej, które szczególnie odczuły skutki kryzysu ekonomicznego końca lat dwutysięcznych: Grecja, Hiszpania, Cypr, Włochy.

- Pozostałe państwa cechujące się zarówno relatywnym wzrostem poziomu rozwoju nowoczesnych usług, jak i czynników rozwoju to państwa Europy Środkowo-Wschodniej. Cechują się one relatywnie wyższą dynamiką rozwoju nowoczesnych usług (przy niższych wartościach wskaźników poziomu ich rozwoju). W tej grupie wyróżniają się: Estonia, Słowenia, Czechy, które cechowała najsilniejsza dynamika wzrostu wartości badanych wskaźników, powodująca przesunięcie tych państw w układzie współrzędnych w prawo, ku górze. Chorwację, Słowację i Słowenię, Węgry, Litwę i Łotwę oraz Polskę cechowała nieco niższa dynamika zmian. W tej grupie państw występują też takie, w których wzrost poziomu rozwoju nowoczesnych usług nie przełożył się jeszcze na wzmocnienie czynników rozwoju. Są to: Bułgaria i Rumunia, cechujące się najniższymi wartościami analizowanych wskaźników.

Specyficznym przykładem jest Luksemburg, który cechuje się wysokim poziomem rozwoju nowoczesnych usług (głównie za sprawą usług dla biznesu, w szczególności finansowych) oraz przy przeciętnych wartościach cech rozpatrywanych jako czynniki rozwoju charakteryzuje się jednocześnie wysokimi wartościami wskaźnika PKB na jednego mieszkańca. Jest to jednak specyficzny typ gospodarki. Przeprowadzona analiza prowadzi do wniosku, że większość państw w procesie rozwoju społeczno-gospodarczego podąża ścieżką prowadzącą od wzrostu nowoczesnych usług, przez wzmacnianie czynników rozwoju społeczno-gospodarczego i w konsekwencji do wyższego poziomu rozwoju nowoczesnej gospodarki (rycina 3).

W kolejnym etapie do analizy zależności włączono również poziom rozwoju społeczno-gospodarczego mierzony wartością PKB na jednego mieszkańca i dokonano typologii państw UE. Grupowanie przeprowadzono z wykorzystaniem analizy skupień w dwóch momentach czasowych, dla lat: 2008 i 2017. W roku 2008 wyróżniono trzy następujące skupienia (rycina 3, tabela 2):

Pierwsze, obejmujące następujące państwa: Dania, Finlandia, Szwecja, Niemcy, Wielka Brytania, Irlandia, Austria, Holandia, Luksemburg. To państwa o relatywnie najwyższych wartościach wskaźników we wszystkich trzech analizowanych wymiarach.

Drugie, obejmujące Włochy, Cypr, Grecję, Maltę, Hiszpanię, Portugalię, a także Belgię, Francję, Czechy, Słowenię i Estonię. 
Rycina 2. Zmiany w relacjach między poziomem rozwoju nowoczesnych usług a czynnikami rozwoju społeczno-gospodarczego w krajach UE w latach 2007-2017

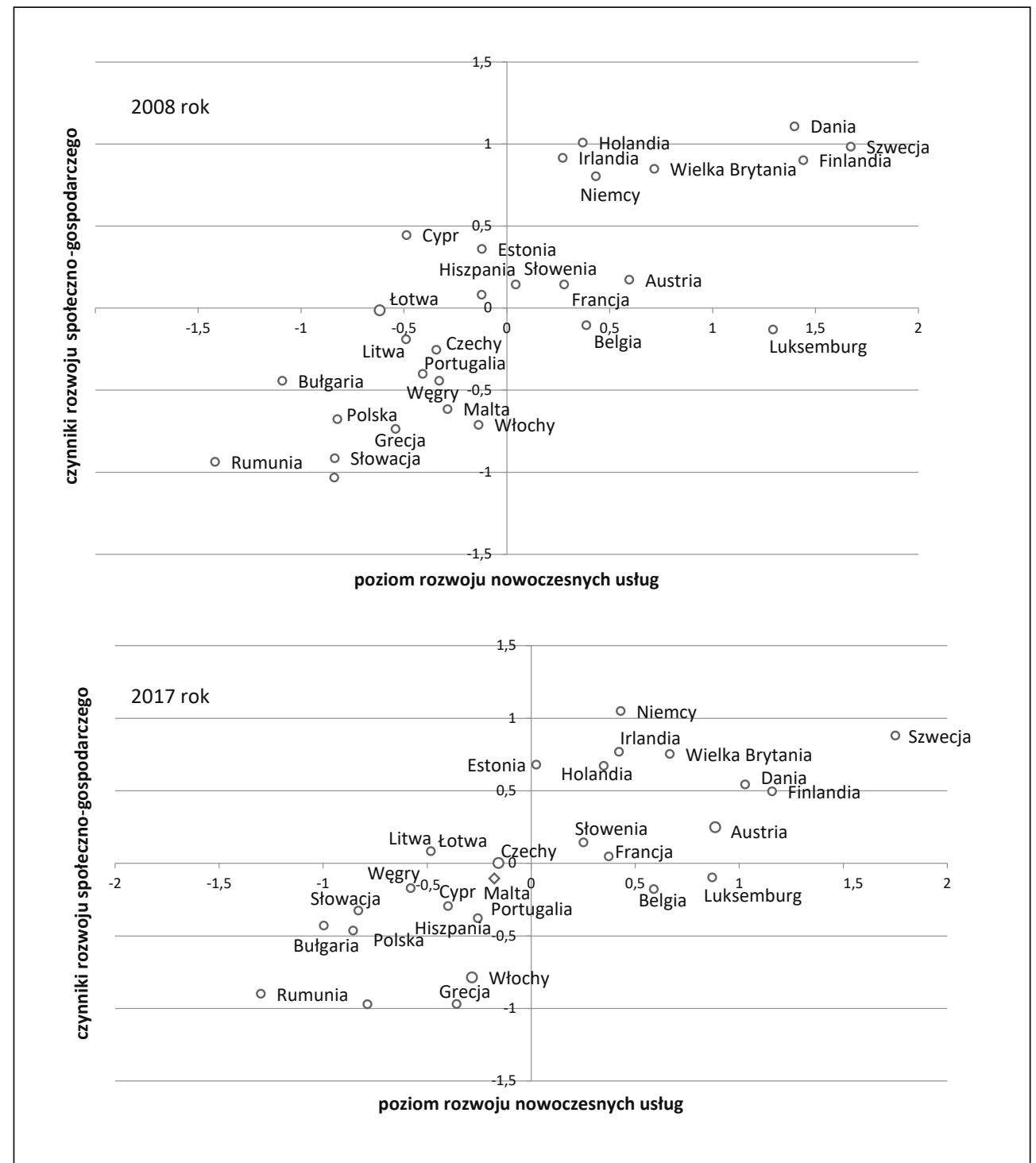

Źródło: opracowanie własne na podstawie danych z bazy Eurostat

Trzecie, obejmujące pozostałe państwa UE: Litwę, Łotwę, Węgry, Słowację, Polskę oraz Rumunię i Bułgarię.

Układ ten nie uległ zasadniczym zmianom w roku 2017. Jedyne odnotowane przesunięcia nastąpiły $\mathrm{w}$ odniesieniu do:

- Belgii, która awansowała z drugiego do pierwszego skupienia;

- Liwy i Łotwy, które awansowały z trzeciego do drugiego skupienia oraz

- Grecji, która z kolei odnotowała spadek ze skupienia drugiego do trzeciego (tabela 2). 
Rycina 3. Klasyfikacja państw UE ze względu na zmiany poziomu rozwoju nowoczesnych usług oraz czynników rozwoju społeczno-gospodarczego
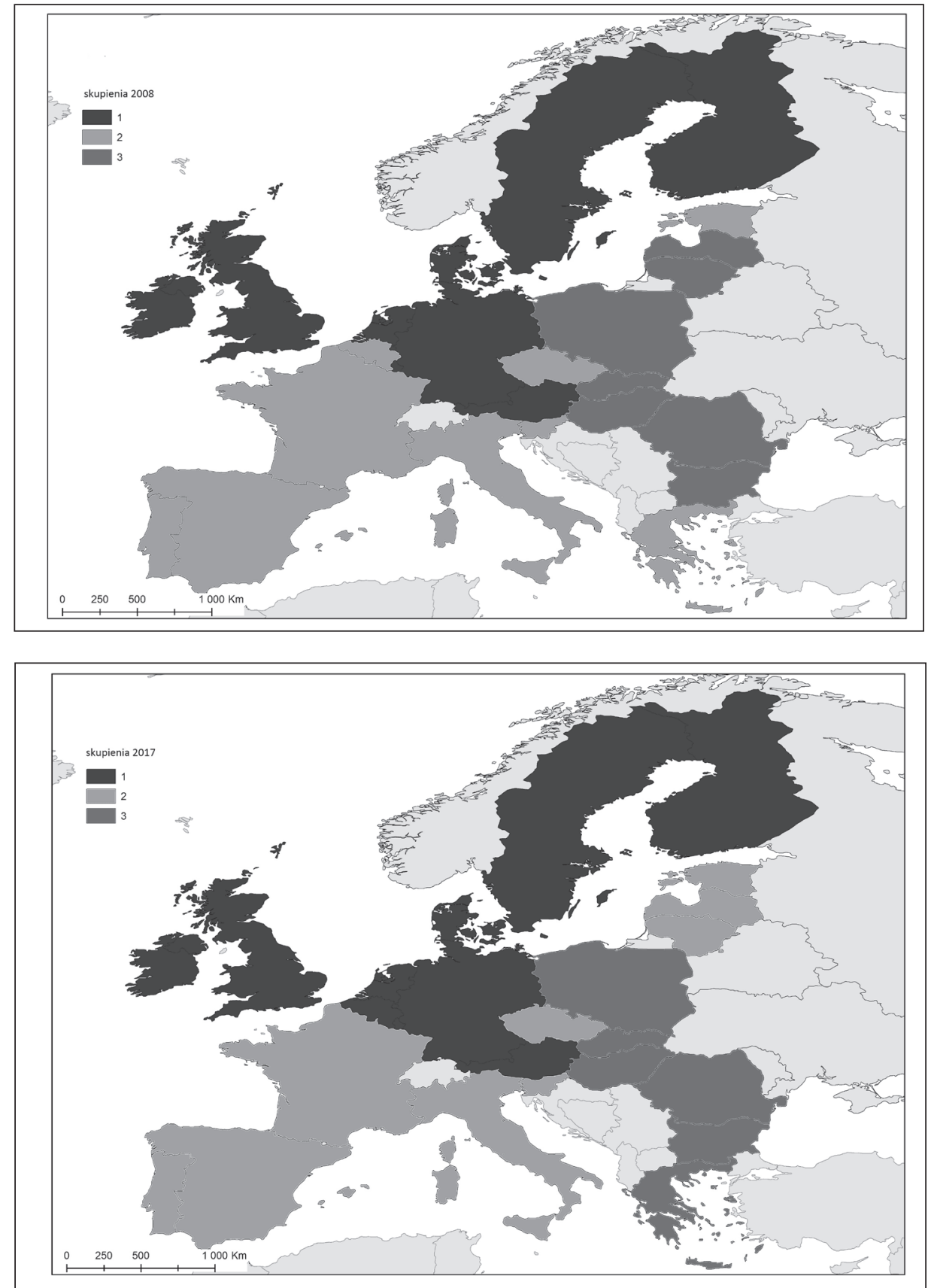

Źródło: opracowanie własne na podstawie danych z bazy Eurostat 
Tabela 2. Skupienia państw UE ze względu na poziom rozwoju nowoczesnych usług oraz czynniki i poziom rozwoju społeczno-gospodarczego

\begin{tabular}{|l|l|l|}
\hline & \multicolumn{1}{|c|}{2008} & \multicolumn{1}{|c|}{2017} \\
\hline Skupienie I & $\begin{array}{l}\text { Dania, Finlandia, Szwecja, } \\
\text { Niemcy, Wielka Brytania, Irlandia, } \\
\text { Austria, Holandia, Luksemburg }\end{array}$ & $\begin{array}{l}\text { Dania, Finlandia, Szwecja, } \\
\text { Niemcy, Wielka Brytania, Irlandia, } \\
\text { Austria, Holandia, Luksemburg, Belgia }\end{array}$ \\
\hline Skupienie II & $\begin{array}{l}\text { Belgia, Francja, } \\
\text { Cypr, Grecja, Włochy, Hiszpania, } \\
\text { Portugalia, Malta, } \\
\text { Czechy, Słowenia, }\end{array}$ & $\begin{array}{l}\text { Francja, } \\
\text { Cypr, Włochy, Hiszpania, } \\
\text { Portugalia, Malta, } \\
\text { Czechy, Słowenia, } \\
\text { Estonia, Litwa, Łotwa }\end{array}$ \\
\hline Skupienie III & $\begin{array}{l}\text { Litwa, Łotwa, } \\
\text { Węgry, Słowacja, Polska, } \\
\text { Rumunia, Bułgaria }\end{array}$ & $\begin{array}{l}\text { Grecja, } \\
\text { Węgry, Słowacja, Polska, } \\
\text { Rumunia, Bułgaria }\end{array}$ \\
\hline
\end{tabular}

Źródło: opracowanie własne na podstawie danych z bazy Eurostat

Rycina 4. Skupienia państw UE ze względu na poziom rozwoju nowoczesnych usług, czynniki i poziom rozwoju społeczno-gospodarczego w 2017 roku

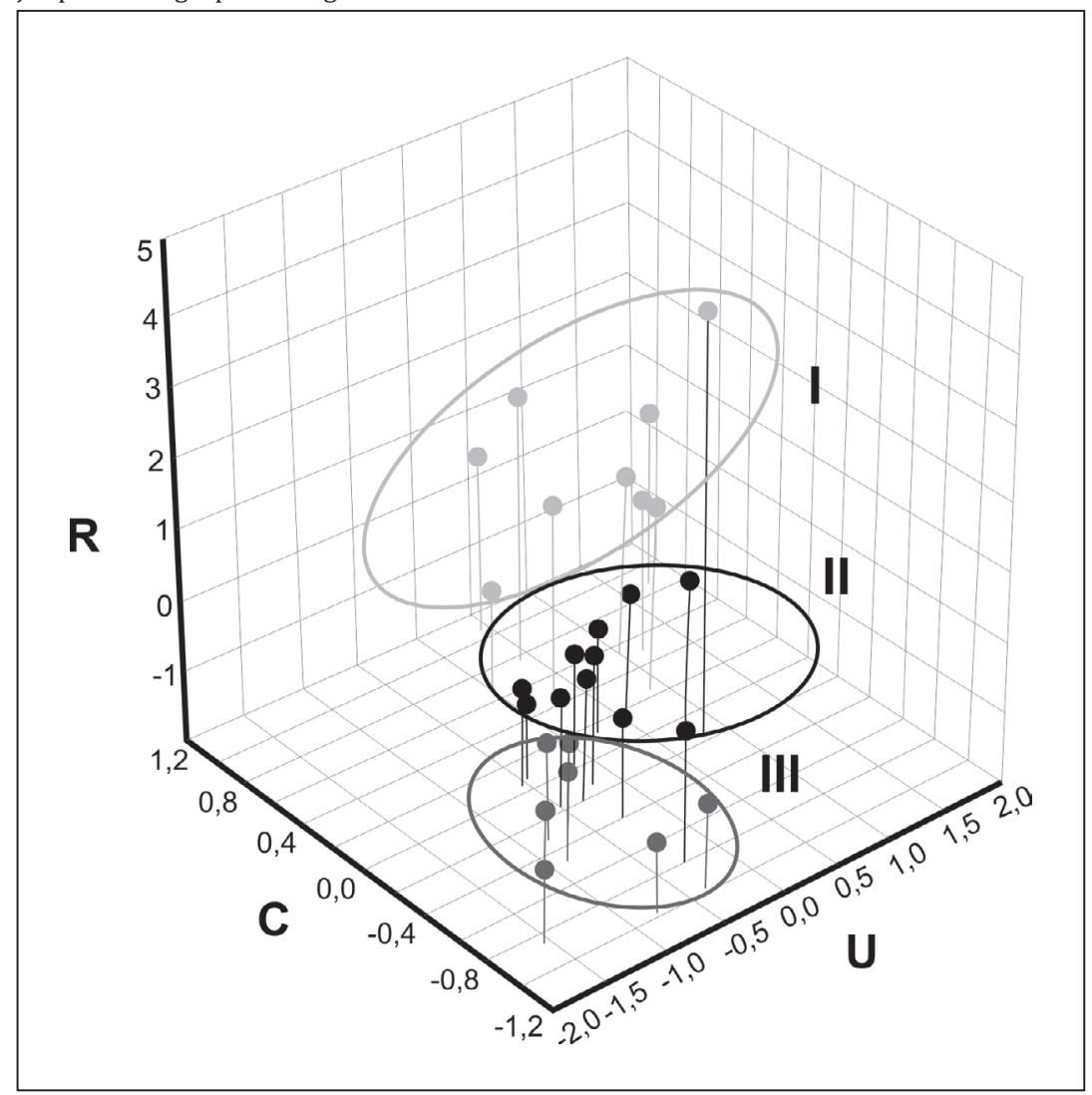

U - wartość syntetycznego wskaźnika poziomu rozwoju nowoczesnych usług

C - wartość syntetycznego wskaźnika opisującego czynniki rozwoju

$\mathrm{R}$ - poziom rozwoju społeczno-gospodarczego mierzonego wartością PKB na 1 mieszkańca

Źródło: opracowanie własne na podstawie danych z bazy Eurostat 
Awans Belgii, Litwy i Łotwy do skupień o wyższych wartościach analizowanych wskaźników wynikał przede wszystkim z relatywnego wzrostu wartości wskaźnika opisującego poziom rozwoju nowoczesnych usług. Spadek Grecji z kolei był związany ze znaczącym spadkiem wartości wskaźników opisujących czynniki i poziom rozwoju społeczno-gospodarczego, co jest konsekwencją kryzysu ekonomicznego końca lat dwutysięcznych. Poza tymi przesunięciami układ i skupienia państw UE mają charakter stały i odzwierciedlają zidentyfikowane wcześniej zależności.

\section{PODSUMOWANIE}

Analiza zmian relacji w zakresie rozwoju nowoczesnych usług, czynników rozwoju oraz poziomu rozwoju społeczno-gospodarczego pozwala na identyfikację pewnych prawidłowości w układzie państw UE. W wyróżnionych skupieniach państw wysokiemu poziomowi rozwoju nowoczesnych usług towarzyszą relatywnie wysokie wartości wskaźników związanych z czynnikami i poziomem rozwoju społeczno-gospodarczego (kraje Europy Zachodniej i Północnej). Niższymi wartościami analizowanych wskaźników charakteryzują się państwa Europy Południowej i Środkowo-Wschodniej. Analiza w ujęciu dynamicznym wykazała, że zmianom w poziomie rozwoju nowoczesnych usług towarzyszą najpierw zmiany w zakresie czynników rozwoju: kapitału ludzkiego, finansowego, innowacyjności i środowiska biznesu, a następnie w poziomie rozwoju społeczno-gospodarczego mierzonego wartością PKB per capita.

Wyniki wcześniej prowadzonych badań nad wpływem nowoczesnych usług na rozwój społeczno-gospodarczy przy wykorzystaniu analizy kanonicznej wskazują, że istnieje istotna statystycznie zależność między nowoczesnymi usługami a poziomem rozwoju społeczno-gospodarczego. Najsilniejszy związek zidentyfikowano w odniesieniu do kapitału finansowego, gdzie $\mathrm{R}^{2}=0,677$. Kluczową rolę tego czynnika potwierdzają także inne badania (Churski, Dominiak, 2014). W pozostałych przypadkach zależność ta nie była tak silna, ale była istotna statystycznie. Zidentyfikowano m.in. istotny wpływ innowacyjności $\left(\mathrm{R}^{2}=0,508\right)$ i kapitału ludzkiego, w szczególności będącego efektem oddziaływania usług edukacyjnych $\left(\mathrm{R}^{2}=0,410\right)$ (Dominiak, 2019). Włączenie do analiz czynników rozwoju społeczno-gospodarczego pozwoliło na przybliżenie mechanizmu tego wpływu. Przeprowadzona analiza prowadzi do wniosku, że większość państw w procesie rozwoju społeczno-gospodarczego podąża ścieżką prowadzącą od wzrostu nowoczesnych usług, przez wzmacnianie czynników rozwoju społeczno-gospodarczego, i w konsekwencji do wyższego poziomu rozwoju nowoczesnej gospodarki.

\section{Literatura \\ References}

Aydalot, P., Keeble, D. (1988). High technology industry and innovative environments: The European expierence. London: Routledge.

Becker, G. (1964, 1993). Human Capital. New York: National Bureau of Economic Research, Columbia University Press.

Camagni, R. (1991). Local "Milieu", Uncertainty and Innovation Networks: Towards a New Dynamic Theory of Economic Space. W: R. Camagni (red.). Innovation Networks: Spatial Perspectives. London: BelhavenPinter, 121-144.

Capello, R., Nijkamp, P. (red.) (2009). Regional growth and development theories in the XXI. Century. Cheltenham: Edwar Elgar. 
Chojnicki, Z., Czyż, T. (2006). Aspekty regionalne gospodarki opartej na wiedzy w Polsce. Poznań: Bogucki Wydawnictwo Naukowe.

Churski, P., Dolata, M., Dominiak, J., Hauke, J., Herodowicz, T., Konecka-Szydłowska, B., Nowak, A., Perdał, R., Woźniak, M. (2018). Współczesne przemiany czynników rozwoju społeczno-gospodarczego. W: P. Churski (red.). Teoretyczne i aplikacyjne wyzwania współczesnej geografii i społeczno-ekonomicznej. Studia Komitetu Przestrzennego Zagospodarowania Kraju Polskiej Akademii Nauk, CLXXXIII, 67-88.

Churski P., Dominiak, J. (2014). The Impact of Innovations on Growth and Stagnation Regions in Poland. European Planning Studies, 22(6), 1143-1164. Carfax, Publishing.

Dominiak, J. (2017). Nowoczesne usługi a poziom rozwoju gospodarczego. Prace Komisji Geografii Przemysłu Polskiego Towarzystwa Geograficznego, 31(1), 81-96.

Dominiak, J. (2018). Modern services: terminological considerations and the characteristic features of their role in socio-economic development. Quaestiones Geographicae, 37(2), 17-25.

Dominiak, J. (2019). Nowoczesne usługi w ujęciu przestrzennym i ich rola w rozwoju społeczno-gospodarczym. Poznań: Bogucki Wydawnictwo Naukowe.

Dominiak, J., Hauke, J. (2019). Badanie wpływu nowoczesnych usług na poziom rozwoju społeczno-gospodarczego z wykorzystaniem dwustopniowej analizy współzależności. Studia Ekonomiczne. Ekonomia, 367.

Felipe, J., Leon-Ledesma, M., Lanzafame, M., Estrada, G. (2007). Sectoral Engines of Growth in Developing Asia: Stylized Facts and Implications. ERD Working Paper Series, 107. Asian Development Bank.

Keeble, D., Wilkinson, F. (1999). Collective learning and knowledge development in the evolution of regional clusters of high technology SME's in Europe. Regional Studies, 33(4), 295-303.

Kłosiński, K. (2000). Zmiany w strukturze wytwarzania usług rynkowych w latach 1990-1998. W: A. Lipowski (red.). Struktura gospodarki transformującej się. Polska 1990-1998 i projekcja do 2010. Warszawa: Polska Akademia Nauk, 175-209.

Kostrubiec, B. (1965). Klasyfikacja dynamiczna i wielocechowa województw Polski. Biuletyn Komitetu Przestrzennego Zagospodarowania Kraju Polskiej Akademii Nauk, 35.

Kowalski, M.A. (2011). Wpływ kryzysu gospodarczego na procesy współpracy i konkurencji. Master of Business Administration, 2(112), 30-42. Akademia Leona Koźmińskiego.

Longhi, C. (1999). Networks, collective learning and technology development in innovative high technology regions: The case of Sophia-Antipolis. Regional Studies, 33(4), 333-342.

Lundvall, B.A. (2000). Gospodarka ucząca się: Pewne implikacje dla bazy wiedzy o systemie ochrony zdrowia i edukacji. W: Zarządzanie wiedza w społeczeństwie uczącym się. Warszawa: Ministerstwo Gospodarki. Departament Strategii Gospodarczej, Centrum Badań nad Edukacją i Innowacją OECD, 117-133.

Markowski, T. Drzazga, D. (red.) (2008). Rola wyższych uczelni w rozwoju społeczno-gospodarczym i przestrzennym miast. Studia Komitetu Przestrzennego Zagospodarowania Kraju Polskiej Akademii Nauk, 121, 33-44.

Nowakowska, A., Feltynowski M. (2009). Metoda oceny potencjału innowacyjnego regionów. W: A. Nowakowska (red.) Zdolności innowacyjne polskich regionów, 11-24.

Pakulska, T. (2005). Podatność innowacyjna Polski na napływ zagranicznego kapitału technologicznie intensywnego. Warszawa: Szkoła Główna Handlowa.

Rodrik, D. (2009). Growth after the crisis. Working Paper, 65. Washington: Commission on Growth and Development.

Uppenberg, K. (2009). Innovation and economic growth. EIB Papers, 14(1).

Werwicki, A. (1998). Zmiana paradygmatu geografii usług. Przegląd Geograficzny, 70(3-4), 249267.

Joanna Dominiak, dr, Wydział Geografii Społeczno-Ekonomicznej i Gospodarki Przestrzennej, Uniwersytet im. A. Mickiewicza w Poznaniu. Adiunkt w Zakładzie Studiów Regionalnych i Lokalnych Wydziału Geografii Społeczno-Ekonomicznej i Gospodarki Przestrzennej Uniwersytetu im. Adama Mickiewicza w Poznaniu. Zainteresowania naukowe koncentrują się wokół roli innowacyjności w kształtowaniu gospodarki opartej na wiedzy, wpływu otoczenia biznesu na rozwój regionów oraz przemian w strukturze usług.

Joanna Dominiak, PhD, Faculty of Socio-Economic Geography and Spatial Management of Adam Mickiewicz University in Poznań. Assistant professor in the Department of Regional Analysis in the Faculty of 
Socio-Economic Geography and Spatial Management of Adam Mickiewicz University in Poznań. Scientific interests revolve around the role of innovation in the development of the knowledge-based economy, the impact of business environment on the development of regions and changes in the structure of services.

ORCID: 0000-0001-9497-8322

\section{Adres/address:}

Uniwersytet im. A. Mickiewicza w Poznaniu

Wydział Geografii Społeczno-Ekonomicznej i Gospodarki Przestrzennej

ul. Krygowskiego 10, 61-680 Poznań, Polska

e-mail:dominiak@amu.edu.pl 